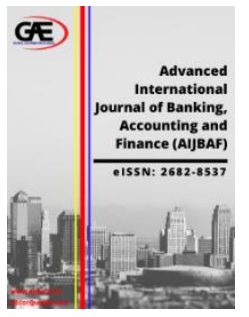

\author{
ADVANCED INTERNATIONAL JOURNAL OF \\ BANKING, ACCOUNTING AND FINANCE \\ (AIJBAF) \\ www.aijbaf.com
}

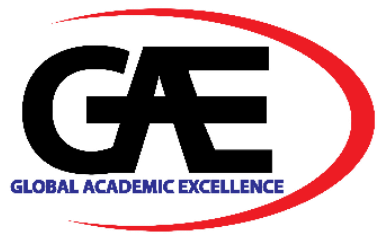

\title{
THE DETERMINANT OF MUDHARABAH DEPOSIT SHARING PROFIT IN INDONESIAN ISLAMIC BANKING
}

\author{
Vika Annisa Qurrata ${ }^{1 *}$, Ermita Yusida ${ }^{2}$, Linda Seprillina ${ }^{3}$, Vidya Purnamasari ${ }^{4}$ \\ 1 Faculty of Economic, Universitas Negeri Malang, Indonesia \\ Email: vika.annisa.fe@um.ac.id \\ 2 Faculty of Economic, Universitas Negeri Malang, Indonesia \\ Email: ermita.yusida.fe@um.ac.id \\ 3 Faculty of Economic, Universitas Negeri Malang, Indonesia \\ Email: linda.seprillina.fe@um.ac.id \\ $4 \quad$ Faculty of Economic, Universitas Negeri Malang, Indonesia \\ Email: vidya.purnamasari.fe@um.ac.id \\ Corresponding Author
}

\section{Article Info:}

\section{Article history:}

Received date: 26.11 .2020

Revised date: 01.12 .2020

Accepted date: 28.02.2021

Published date: 05.03.2021

\section{To cite this document:}

Qurrata, V. A., Yusida, E., Seprillina, L., \& Purnamsari, V. (2021). The Determinant of Mudharabah Deposit Sharing Profit in Indonesian Islamic Banking. Advanced International Journal of Banking, Accounting, and Finance, 3 (6), 37-50.

DOI: $10.35631 /$ AIJBAF.36004.

This work is licensed under CC BY 4.0

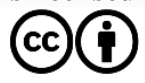

\begin{abstract}
:
The potential of Islamic banking in Indonesia is overgrowing along with the increasing public understanding of Islam. In Islamic Banking, various products have been offered to attract the interest of the public. However, the most popular product is savings because it is the safest product for high yields. Mudharabah deposits are fundraising products that provide the largest proportion of total third-party funds. This study aims to compare the results of a comparison between finances represented by the Non-Performing Financing (NPF) and the Return on Investment (ROI) for the profit-sharing in mudharabah deposits. The type of method used in this research is the quantitative descriptive method. The data source is obtained from secondary data sourced from monthly reports issued through all Islamic banks' websites in Indonesia or the official BI website from 2008 to 2017. The results of this study indicate the NPF variable is not following the short and long-term plans for profit sharing of deposits mudharabah. Moreover, the ROI variable has a significant positive effect on the short and long-term results of mudharabah deposits. This research concludes that in the short and long term, NPF is not intended for results. It relates to the bank having a good reserve and analyzing the issues that need to be considered. Meanwhile, ROI is attractive towards revenue sharing because more increase the bank revenue gives the rising impact of income.
\end{abstract}

Keywords:

Non Performing Financing (NPF), Return on Investment (ROI), Mudharabah Deposits' Profit Sharing, Indonesian Islamic Bank 
Volume 3 Issue 6 (March 2021) PP. 37-50 DOI 10.35631/AIJBAF.36004

\section{Introduction}

The potential of Islamic banking in Indonesia is proliferating and increasing the understanding of the Muslim community about Islam. It can be seen with the more establishment of Islamic banking. Even conventional banking also opened a subsidiary of Islamic banks. Not only that, but even Bank Indonesia also has different instruments for Islamic and conventional banking. Therefore, Islamic banking began to aggressively offer Islamic products to be increasingly in demand by the public.

Changing society's mindset from conventional banking to Islamic banking is certainly uneasy because everyone has rationality, which is often referred to as bounded rationality. So many customers also compare the benefits of putting their funds in Islamic or conventional banking. Every individual wants profits, but not only that, Islamic banking exists to offer enormous and beneficial benefits. One factor that customers consider in investing their funds in Islamic banking is profit sharing (Husnelly, 2003; Mangkuto, 2004).

Deposits are the most secure banking products with high-profit sharing, so they are much in demand by the public. In Islamic banking where mudharabah deposits are fund raising products that provide the largest proportion of total third-party funds. From 2013 to 2018, we can see that third-party funds growth was more significant than the growth of financing disbursed (PYD) were grew by 13.09 percent, while PYD only grew by 11.25 percent (Figure 1.).

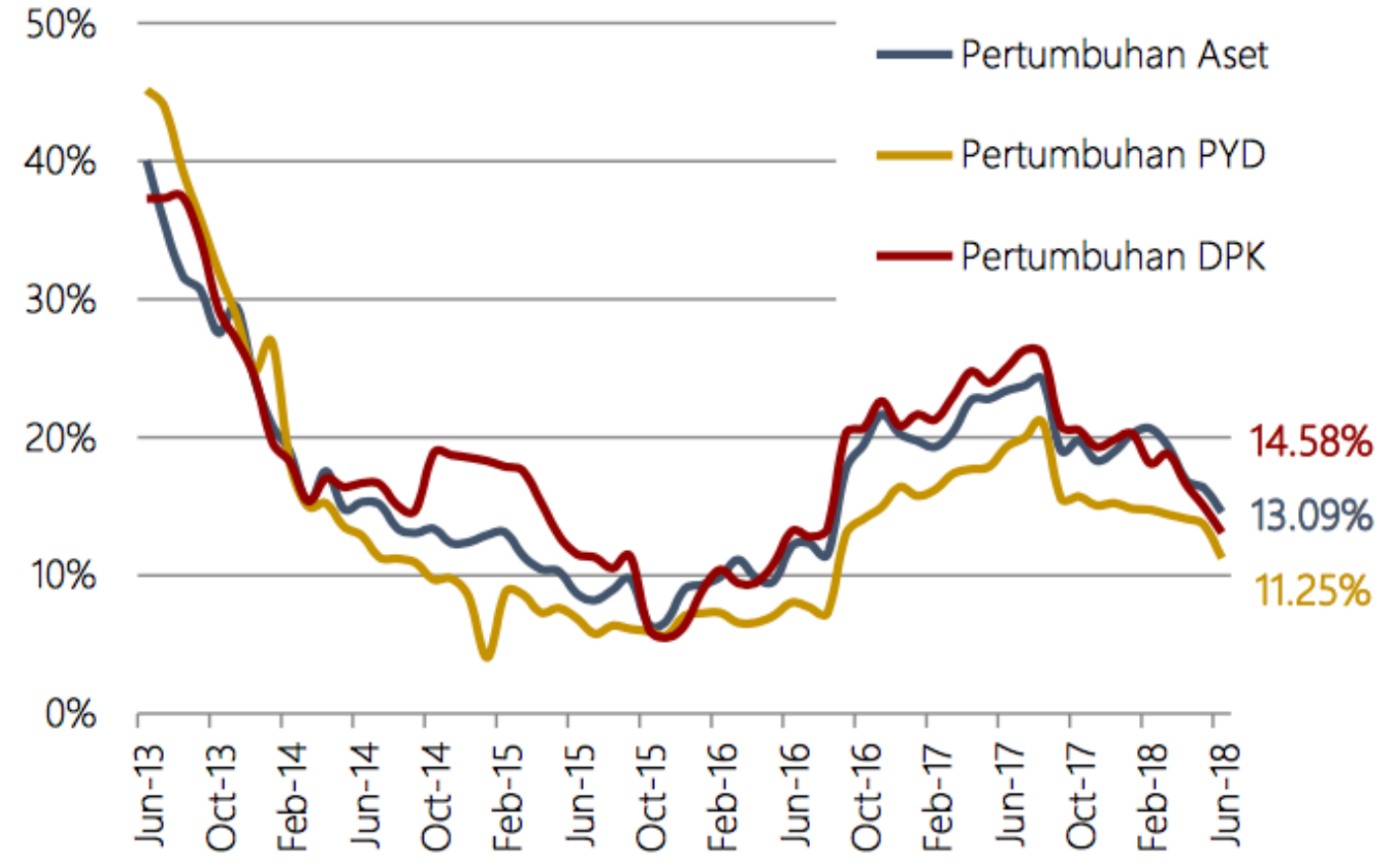

Figure 1. The Development of Sharia Banking Financial Main Indicators in Indonesia

Furthermore, the largest component of growth in Third Party Funds is the large deposit rate. Based on Figure 2, the proportion of Deposits to Third Party Funds in 2018 reached 57.42 percent. It indicates that Islamic banking products that can be improved are Mudhorobah deposits. Seeing the potential of Muslim communities and the tendency of people to choose sharia products with the least risk level. 
Volume 3 Issue 6 (March 2021) PP. 37-50

DOI 10.35631/AIJBAF.36004

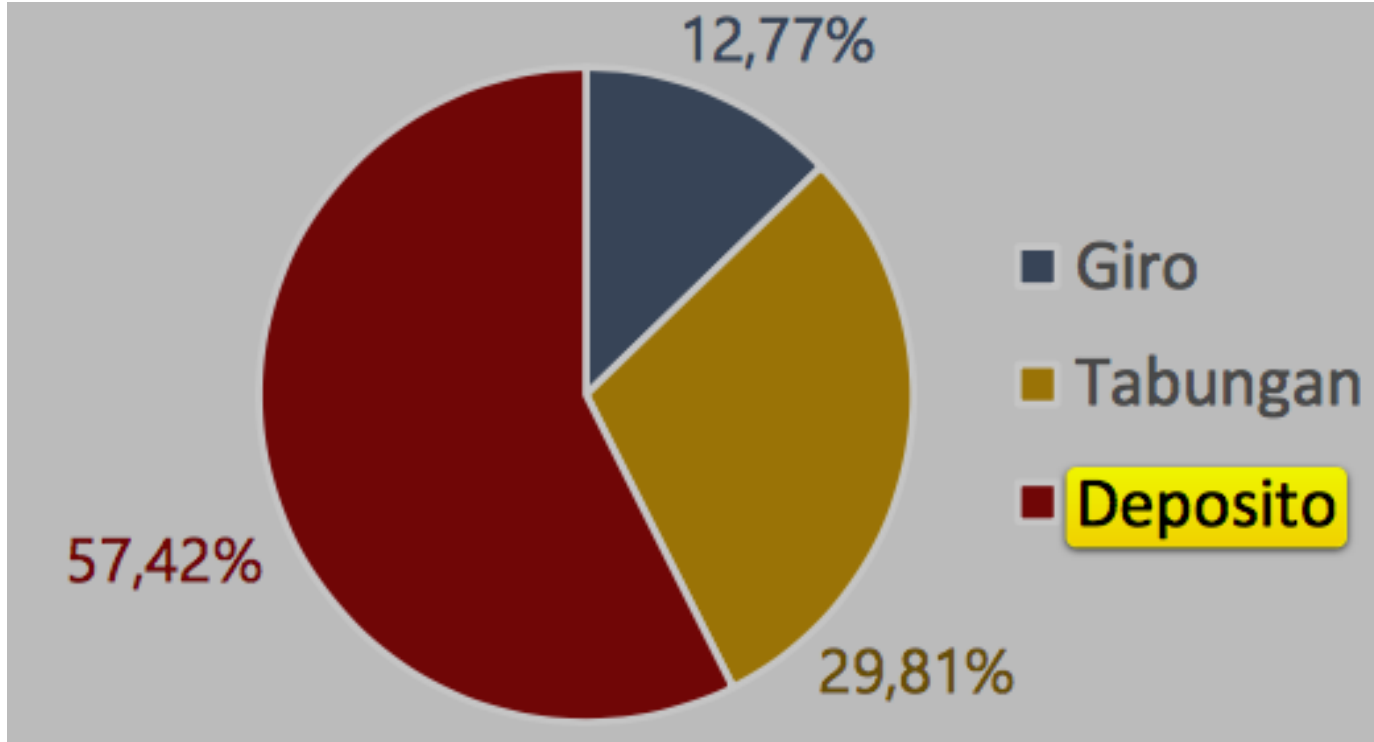

Source: Otoritas Jasa Keuangan (OJK), 2018

\section{Figure 2. Components of Third Party Funds for Islamic Banking in Indonesia in 2018}

Islamic Banking performance is increasing customer interest in Indonesia. Thus, it will develop the number of Mudharobah Deposits in Indonesia. Referring to Bank Indonesia Regulation No. 9/1 / PBI / 2007, its evaluation uses the CAMELS approach (Capital, Asset, Management, Earning, Liquidity and Market Risk Sensitivity). CAMEL is an official measurement tool established by Bank Indonesia to calculate Islamic banks' health in Indonesia. This ratio is considered more helpful for customers to find out the ideal return rate derived from mudharabah deposits and shareholder equity. Many papers found that Return determines sharing profit on Assets (ROA), Non-Performing Financing (NPF), and Financing to Deposit Ratio (FDR). However, it never mentions the impact of Return on Investment (ROI) on sharing profit that investment is one of the bank's funding resources. Therefore, this study's main objective is to identify The Determinant of Mudharabah Deposit Sharing Profit in Indonesian Islamic Banking.

\section{Literature Review}

There are three points will be discussed in literature review such as the existence of Islamic Banks, the measurement of Islamic Banking financial performance, and Mudharabah Deposits. Further explanations are mention below.

\section{The Existence of Islamic Banks}

According to the Law of the Republic of Indonesia No. 21 of 2008 concerning Sharia Banking, sharia banks are banks that carry out their business activities based on sharia principles and by type consist of Sharia Commercial Banks and Sharia Rural Credit Banks. According to Sudarsono (2007), Islamic banks or profit-sharing banks are banks that operate using Islamic sharia principles. Which in operation follows the rules of the Koran and Al-Hadith and regulations from the government. According to Wiroso (2005), the understanding of Islamic Banks is an intermediary institution that carries out its operational activities by collecting funds from the public through two principles, namely the wadiah yad dhamanah principle and the mudharabah muthlaqah principle. Then the sharia bank funds collected are channeled with 
Volume 3 Issue 6 (March 2021) PP. 37-50

DOI 10.35631/AIJBAF.36004

sharia-justified fund distribution patterns. Based on these definitions, it can be said that an Islamic bank or a sharia bank is a financial institution that in its management and operation uses Islamic principles or sharia principles contained in the Al-Quran and Al-Hadith.

The activities of Islamic banks are the implementation of Islamic economic principles with characteristics (Wiyono, 2005):

a. Prohibition of usury in various forms.

b. Do not recognize the concept of the time value of money (time value of money).

c. The concept of money as a medium of exchange rather than a commodity.

d. It is not permissible to carry out speculative activities.

e. It is not allowed to use two prices for one item.

f. Not allowed two transactions in one contract.

Islamic Banks in running their business have at least five operational principles consisting of (Antonio, 2012):

a. Pure Deposit Principle

The principle of pure savings is a facility provided by Islamic banks to provide opportunities for parties with excess funds to save their funds in the form of al-wadi'ah, which are usually given for investment purposes to obtain benefits such as savings and deposits. In the world of conventional banking, al-wadi'ah is identical to demand deposits.

\section{b. Revenue Sharing}

This system includes procedures for the distribution of results of operations between fund providers and fund managers. The division of profits can occur between banks and depositors of funds and between banks and customers receiving funds. Forms of products based on this principle are Mudharabah and Musyarakah. Furthermore, the Mudharabah principle can be used as a basis for funding products (savings and time deposits) and financing, while Musyarakah is more for financing.

c. Principles of Sale and Purchase

This principle is a system that implements the procedure of buying and selling, in which the bank will buy the goods needed first or appoint the customer as an agent of the bank to buy goods on behalf of the bank, then the bank sells the goods to the customer at the price of a purchase price plus profit.

\section{d. Rental Principle}

This principle is broadly divided into two types:

1) Ijarah, pure rent, as is the rental of tractors and other product tools (operating lease).

In banking technical, banks can buy equipment needed by the customer first, then rent it in time and only what has been agreed to the customer.

2) Bai al takjiri or ijarah al muntahiyah bitamlik is a combination of rent and purchase, where the tenant has the right to own the goods at the end of the rental period.

\section{e. Principle of fee/service}

This principle covers all non-financing services provided by banks. Forms of products based on this principle include Bank Guarantees, Clearing, Collections, Transfer Services, and others. This principle is based on the concept of al-ajr wal umulah. 


\section{The Measurement of Sharia Banking Financial Performance}

Performance is defined as something that the company achieves and reflects its condition in a certain period. According to Jumingan (2006), performance is an important thing that must be achieved by every company everywhere because performance is a reflection of the company's ability to manage and allocate its resources.

According to Fahmi (2012), financial performance is a picture of the company's success can be interpreted as the results that have been achieved for various activities carried out. It can be explained that financial performance is an analysis conducted to see the extent to which a company has carried out using the rules of financial implementation correctly and adequately. Meanwhile, according to Sucipto (2003), the notion of financial performance is the determination of specific measures that can measure the success of an organization or company in generating profits.

From some of the above income, it can be concluded that financial performance is the achievement of bank achievements in a period that illustrates the condition of bank financial health with indicators of capital adequacy, profitability, and bank efficiency. Financial performance can also show the quality of banks through the calculation of financial ratios.

\section{Non Performing Financing (NPF)}

As an indicator that shows losses due to credit risk is reflected in non-performing loans (NPL), Islamic banks' terminology is called non-performing financing (NPF). Non-Performing Financing (NPF) is the ratio between problematic financing and total financing channeled by Islamic banks. Based on Bank Indonesia's criteria, the categories included in the NPF are substandard, doubtful, and loss financing.

$$
\mathrm{NPF}=\frac{\text { Impaired financing }}{\text { Total financing }} \times 100 \%
$$

Based on Bank Indonesia Regulation Number 8/21 / PBI / 2006 concerning Quality Assessment of Commercial Banks conducting business activities based on sharia principles article 9 paragraph (2), that the quality of productive assets in the form of financing is divided into five

\begin{tabular}{|c|c|c|c|}
\hline \multirow[t]{2}{*}{ Financing } & \multicolumn{3}{|c|}{ Categorized of Non Performing Financing } \\
\hline & Substandard & Doubtful & Loss \\
\hline $\begin{array}{l}\text { Murabahah, } \\
\text { Istishna', Ijarah, } \\
\text { Qard }\end{array}$ & $\begin{array}{l}\text { Arrears for more } \\
\text { than } 90 \text { to } 180 \\
\text { days }\end{array}$ & $\begin{array}{l}\text { Arrears for more } \\
\text { than } 180 \text { to } 270 \\
\text { days }\end{array}$ & $\begin{array}{l}\text { Arrears for more than } 270 \\
\text { days }\end{array}$ \\
\hline Salam & $\begin{array}{l}\text { Due date on } 60 \\
\text { days }\end{array}$ & $\begin{array}{l}\text { Due date on } 90 \\
\text { days }\end{array}$ & More than 90 days \\
\hline $\begin{array}{l}\text { Mudharabah, } \\
\text { Musyarakah }\end{array}$ & $\begin{array}{l}\text { Arrears for } 90 \\
\text { days. } \\
\text { Revenue sharing } \\
\text { is above } 30 \% \text { to }\end{array}$ & $\begin{array}{l}\text { Arrears for more } \\
\text { than } 90 \text { to } 180 \\
\text { days. }\end{array}$ & $\begin{array}{l}\text { Arrears for more than } 180 \\
\text { days. } \\
\text { Revenue realization of } \\
\text { less than } 30 \% \text { of projected }\end{array}$ \\
\hline
\end{tabular}
groups, namely pass, special mention, substandard, doubtful, loss.

Tabel 1: NPF calculation based on the ability of payment customers at Islamic banks

Copyright $\odot$ GLOBAL ACADEMIC EXCELLENCE (M) SDN BHD - All rights reserved 
Volume 3 Issue 6 (March 2021) PP. 37-50

DOI 10.35631/AIJBAF.36004

\begin{tabular}{|l|l|l|l|}
\hline & $\begin{array}{l}\text { 90\% of project } \\
\text { revenue }\end{array}$ & $\begin{array}{l}\text { Revenue sharing is } \\
\text { less than 30\% }\end{array}$ & $\begin{array}{l}\text { income over 3 payment } \\
\text { periods. }\end{array}$ \\
\hline
\end{tabular}

Source: Muntoha (2011)

Non-performing financing (NPF) will have an impact on decreasing the level of revenue sharing that is distributed to fund owners. The relationship between the bank and the customer is based on two interrelated elements: law and trust. A bank can only carry out activities and develop its business if the customer believes in placing the money. After collecting funds from the public in the form of deposits, the bank then distributes them back to the community to improve the people's standard of living (Rahma Wulan in Muntoha, 2011). According to Antonio (2012), cost control has a relationship to banking institutions' performance, so the lower the level of NPL (tighter credit policy), the smaller the amount of funding channeled by banks, and vice versa. The tighter the bank's credit financing policy (the more suppressed the NPF level) will cause the level of demand for financing by the public to fall. Maryanah in Choirudin and Praptoyo (2017) stated that Non-performing financing (NPF) is the financing percentage of problematic outcomes on overall financing. The need for financing loss allowance becomes high when the problem financing is also high; therefore, the ratio of NPF can affect the low level of financing.

\section{Return of Investment (ROI)}

Return on Investment (ROI) analysis in financial analysis has a significant meaning as a comprehensive financial analysis technique. This ROI analysis is an analytical technique commonly used by the banking world to measure overall bank operations effectiveness. ROI itself is one form of profitability ratio intended to measure banks' ability with general funds invested in assets used for bank operations to generate profits. Thus, Return on Investment (ROI) connects the profits derived from the company's operations with the amount of investment or assets used to produce these operating profits (Munawir, 2007). Return on Investment (ROI) is a ratio that shows the results (Return) of the number of assets used in banking or a measure of management efficiency. This ratio shows the results of all assets controlled by ignoring the source of funding, and a percentage usually measures this ratio. (Kasmir 2011). The formula used to find ROI, according to Kasmir (2011), is as follows:

$$
\mathrm{ROI}=\frac{(\text { Total sales }- \text { Investment })}{\text { Investment }} \times 100 \%
$$

Factors that can affect ROI include

1. Turnover of operating assets or turnover rate of assets used for operational activities, namely the speed at which operating assets are rotated within a certain period.

2. Profit margin is the amount of operating profit expressed in terms of percentage and net sales. Profit margins can measure a company's profitability and be linked to sales.

ROI as a form of profitability ratio analysis technique is significant in a company because by knowing ROI, entrepreneurs can find out how efficiently the company utilizes assets for operational activities and provides information on the company's profitability. 


\section{Mudharabah Deposits}

According to Law No. 10 of 1998 article 1 paragraph 7, deposits are depositing whose withdrawals can only be made at a specific time according to the agreement between the depositor and the bank concerned. Meanwhile, according to Law No. 21 of 2008 Article 1 concerning Islamic Banking, time deposits are investment funds based on mudharabah contracts or other contracts not contrary to sharia principles, which can only be withdrawn at a particular time based on the contract between the depositing customer and the sharia bank. At the same time, investments are funds entrusted by customers to Islamic banks based on mudharabah agreements or other contracts that are not in conflict with Islamic principles in deposits, savings, or other forms equivalent.

In this case, Islamic banks act as mudarib (fund managers), while customers act as shahibul mal (fund owners). In its capacity as a mudarib, Islamic Banks can carry out various businesses that do not conflict with Islamic principles and develop them, including entering into mudharabah agreements with third parties (Karim, 2004).

From the results of the management of the mudharabah fund, the Islamic Bank will distribute it to the fund owner under the agreed ratio outlined in the account opening agreement. In managing these funds, the bank is not responsible for losses that are not caused by negligence. However, if what happens is mismanagement, the bank is fully responsible for the loss (Karim, 2004). Based on DSN-MUI Fatwa Number 3 of 2000, deposits that are justified in sharia are deposits based on the mudharabah principle. In mudharabah deposit transactions, the customer acts as the owner of the funds (shahibul maal), and the bank acts as the fund manager (mudharib).

According to Ismail (2011), mudharabah deposits are investment funds placed by customers that are not in conflict with sharia principles and withdrawals can only be made at certain times, per the contractual agreements entered into by the bank and investor customers. Deposits are easy to predict the availability of funds because there is a period in placement. The nature of deposits is that withdrawals can only be made according to the time so that in general, the remuneration in the form of profit-sharing ratio provided by banks for deposits is higher than that of mudharabah savings.

From the above opinions, the definition of mudharabah deposits is public deposits deposited with Islamic Bank, can be in the form of rupiah or foreign exchange where the withdrawal can only be done based on a predetermined period and agreed between the customer and the sharia bank using sharia principles (profit sharing) with a mudharabah agreement. Usually have a period of $1,3,6$, and 12 months.

The Islamic basis for deposits is regulated in DSN Fatwa No. 03 / DSN-MUI / IV / 2000, which states that the community's needs in improving welfare and investment require banking services. One of the banking products in collecting funds from the public is deposits, which are time deposits that can only be withdrawn at a specific time based on a customer deposit agreement. 
Volume 3 Issue 6 (March 2021) PP. 37-50

DOI 10.35631/AIJBAF.36004

Based on this MUI DSN, sharia-justified deposits are based on the mudharabah principle. The provisions are as follows:

1. In this transaction, the customer acts as shahibul maal or fund owner, and the bank acts as mudarib or fund manager.

2. In its capacity as a mudarib, a bank can conduct various businesses that are not contrary to Islamic principles and carry them, including mudharabah with other parties.

3. Capital must be expressed in terms of amounts, in the form of accounts and non-loans.

4. Profit-sharing is stated in the form of a ratio and stated in the account opening agreement.

5. Banks as mudarib cover the operational costs of deposits by using the profit ratio that is due.

\section{Profit Sharing Rate for Mudharabah Deposits}

According to Ascarya (2011), profit sharing is a system of sharing the results of the operations in which the capital owner cooperates with the capital manager to carry out business activities. If the business activities generate profits, they are shared, and when they suffer losses, they will be borne together. The production sharing system guarantees justice, and there is no exploited party. According to Agustianto (2005), profit sharing is the profit or the results obtained from the management of both investment funds and buying and selling transactions provided by customers. From the above income, it can be concluded that revenue sharing is a system used in Islamic Banking in determining the portion obtained by each party, namely between the bank and the customer.

The provisions of the principle of revenue sharing consist of (Wiroso, 2005):

1. The decision profit-sharing share will be made at the time of the contract based on the possibility of profit and loss.

2. The size of the profit-sharing ratio is based on the amount of profit gained.

3. The number of revenue sharing will follow the amount of revenue.

4. Nobody doubts profit sharing.

5. Revenue sharing depends on the profit of the project being carried out. If the project does not benefit, the loss will be shared by both parties.

As an intermediary financial institution, Islamic Banks will profit from funds placed in their partners (ratio). The profit-sharing from this ratio will later be distributed to savers. Islamic Banks need to consider the profit-sharing calculation mechanism, which consists of two systems (Sharia Banking Development Team of the Indonesian Bankers Institute, 2001):

1) Profit Sharing is the calculation of profit-sharing based on the net of total revenue after deducting costs incurred to obtain the income.

2) Revenue Sharing is the calculation of profit-sharing based on the total income received before deducting the costs incurred.

The principle of calculating revenue sharing is fundamental to determine at the beginning and to be known by both parties who will enter into a business cooperation agreement because if this is not done, then it has become gharar, so the transaction is not in accordance with Islamic principles (Rizal, 2009). In practice, there are terms of revenue sharing and profit-sharing. The revenue referred to in the basis of Islamic Bank profit sharing and what has been practiced so far is revenue minus the cost of goods sold. 
It seems that not all indicators of financial performance affect the increase in mudharobah deposits. As the research results from Ferianto (2014) on Islamic commercial banks in Indonesia stated, ROA and BI-Rate partially affect the profit-sharing rate of mudharobah deposits. Whereas BOPO partially has no significant effect on the profit-sharing rate of mudharobah deposits. Furthermore, the research results from Faza and Laily (2018) explain that the variable Return on Assets has a significant adverse effect on the profit-sharing rate of mudharobah deposits. The Financing to Deposit Ratio variable has a significant positive effect on the profit-sharing rate for mudharobah deposits. In contrast to the Return on Equity variable results, which has no effect on the profit-sharing rate of mudharobah deposits in Islamic Commercial Banks for the 2012-2017 period.

\section{Literature Framework}

Based on the theoretical basis and the results of previous studies and the problems raised, then as a reference for formulating hypotheses, the following theoretical thinking framework is presented in the research model as shown in Figure 3.

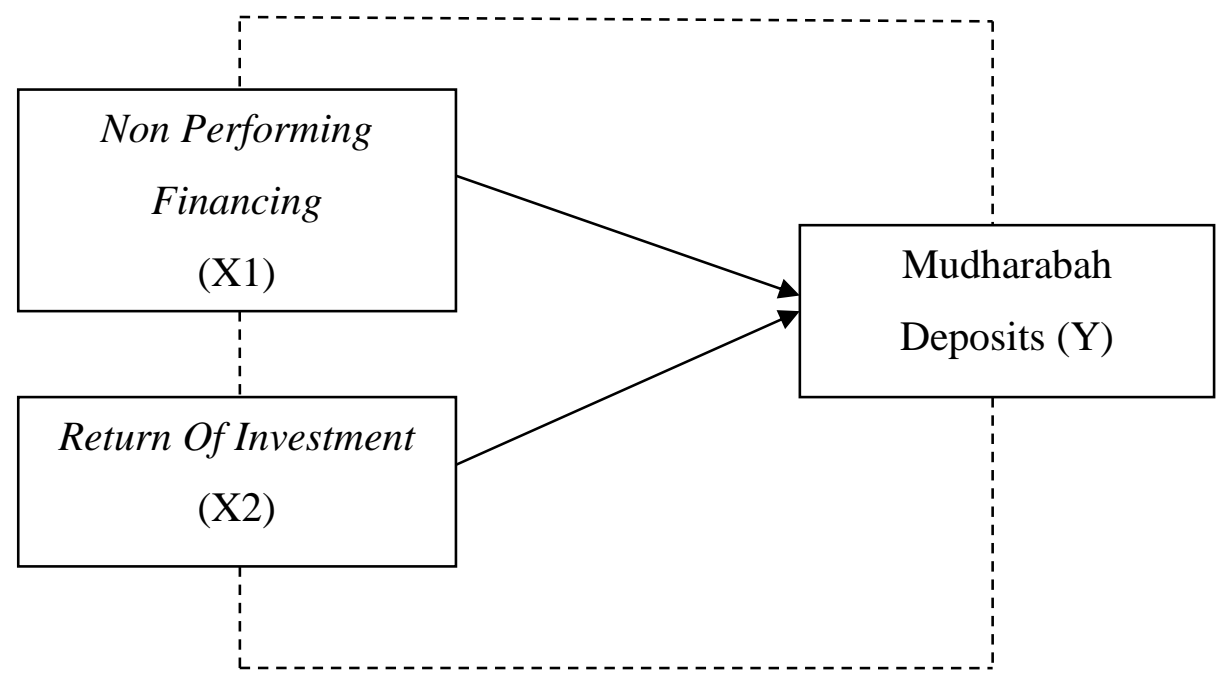

Source: Writer's Illustration, 2018

Figure 3. Research Framework

Keterangan:

X1 : Non Performing Financing (NPF) (Independent variabel)

X2 : Return Of Investment (ROI) (Independent variabel)

Y : Mudharabah Deposits (Dependent variabel)

$\longrightarrow$ : Independent variabel has impact on dependent variabel (parsial)
- : Independent variabel has impact on dependent variabel (simultan) 
The Hypothesis proposed by this researcher is as follows:

a. H0: Credit variable (NPF) has no effect on the profit-sharing rate of mudharabah deposits at Islamic Commercial Banks in Indonesia.

b. Ha: Credit variable (NPF) has a significant effect on the profit-sharing rate of mudharabah deposits at Islamic Commercial Banks in Indonesia.

c. H0: Investment variable (ROI) has no effect on the profit-sharing rate of mudharabah deposits at Islamic Commercial Banks in Indonesia

d. Ha: Investment variable (ROI) has a significant effect on the profit-sharing rate of mudharabah deposits at Islamic Commercial Banks in Indonesia.

\section{Methodology}

\section{Data Types and Analysis}

The type of method used in this research is the quantitative descriptive method. Data are obtained from secondary data sourced from monthly reports published through the company's website or the official BI website from 2008 to 2017. Analysis of the data used in this study uses multiple linear regression analysis with the ordinary least square equation or Ordinary Least Square (OLS). The formed regression equation is as follows:

$$
\begin{aligned}
& \mathrm{Y}=\mathrm{a}+\mathrm{b} 1 \mathrm{X} 1+\mathrm{b} 2 \mathrm{X} 2+\mathrm{e} \\
& \text { Whereas: } \\
& \mathrm{Y}=\text { Mudharabah Deposits } \\
& \mathrm{a}=\text { Constanta } \\
& \mathrm{b} 1=\text { slope } \\
& \mathrm{X} 1=\mathrm{NPF} \\
& \mathrm{X} 2=\mathrm{ROI} \\
& \mathrm{e}=\text { residual }
\end{aligned}
$$

Ensuring good test results, an analysis is also carried out through the classical assumption test.

\begin{tabular}{|c|c|c|c|c|c|c|}
\hline Source | & SS & df & MS & Number of obs & $=$ & $\begin{array}{c}40 \\
18.11\end{array}$ \\
\hline Model & 223.581927 & 2 & 111.790964 & Prob $>F$ & & 0.0000 \\
\hline Residual & 228.443131 & 37 & 6.17413866 & R-squared & $=$ & 0.8746 \\
\hline Total | & 452.025058 & 39 & 11.5903861 & $\begin{array}{l}\text { Adj R-squared } \\
\text { Root MSE }\end{array}$ & i & $\begin{array}{l}0.80 / 3 \\
2.4848\end{array}$ \\
\hline
\end{tabular}
So, the results in this paper are free from heteroscedasticity, multicollinearity, and autocolinearity problems.

\section{Results and Discussions}

\section{Estimated Results}

Based on the estimation of the regression can be obtained the results of multiple linear regression as the Table below.

\section{Tabel 2. Multiple Linear Regression Results}




\begin{tabular}{|c|c|c|c|c|c|c|}
\hline ln_deposit | & Coef. $s$ & Std. Err. & $\mathrm{t}$ & $P>|t|$ & [95\% Conf. I & [nterval] \\
\hline ln_ROI | & .8981696 & 1999801 & 4.49 & 0.000 & .4929715 & 1.303368 \\
\hline ln_NPF & .1053821 & 1. .1232153 & 0.86 & 0.398 & -.1442757 & .35504 \\
\hline _cons | & .4227714 & 1.129639 & 0.37 & 0.710 & -1.866095 & 2.711638 \\
\hline
\end{tabular}

Source: Estimation results, 2019

Based on the regression results in table 2. Multiple linear regression models can be used to identify the effect of independent variables on the dependent variable. In this case, the variable Non-Investment Returns and Non-Performance Financing can be used to identify how much influence it has on mudhorobah deposits. It can be seen from the Prob value $>\mathrm{F}$ significant at the 1 percent level. Additionally, the R-Squared value is also 87 percent, which means that 87 percent of the estimation results can be trusted.

Furthermore, only ROI can significantly influence Mudhorobah Deposits with an error rate of 1 percent from two independent variables. In comparison, NPF has no significant effect on mudhorobah deposits because it has an error rate of more than 5 percent. Likewise with constanta. The estimation results are valid with the classic assumption test results that are free from multicollinier, heterocesdacity, autocorelacy, and normality.

\section{Discussion}

In the banking world, financial statements are essential indicators for related stakeholders, especially banking customers. Through financial reports, it can be seen how the banking conditions are excellent or vice versa. It also happened to the development of Islamic banking in Indonesia.

Based on the estimation results of multiple linear regression, it can be seen that the level of mudhorobah deposits is influenced by the amount of Return on Investment (RoI). If the RoI rises by 1 percent, the mudhorobah profit-sharing deposit rate rises by 0.898 percent. This result can be trusted by looking at the R square value of 87 percent. The equation model can be used to estimate the size of the variables that can affect the Mudhorobah profit share. More clearly can be seen in the following table.

Tabel 3. Regression Estimation Results

\begin{tabular}{|l|c|c|l|}
\hline Variable & Coefficient & $\mathrm{P}>|\mathrm{t}|$ & Notes \\
\hline ROI & 0.898 & 0.000 & Significant at 1\% error level \\
\hline NPF & 0.105 & 0.398 & Unsignificant at 5\% error level \\
\hline Constanta & 0.423 & 0.710 & Unsignificant at 5\% error level \\
\hline
\end{tabular}

source: data processed, 2019

In contrast to research conducted by Umiyati and Shella (2018), Nofianti et al. (2015), and Farianto (2014), this study looks at the effect of Return on Investment (ROI) on the profitsharing of mudharabah deposits. Based on the estimation results in Table 1, between the two variables used, namely ROI and NPF, it turns out that ROI only influences Mudharabah profit sharing. ROI is more trusted as a community benchmark to see how banks benefit from their 
Volume 3 Issue 6 (March 2021) PP. 37-50 DOI 10.35631/AIJBAF.36004

investment activities. ROI is an indicator of bank efficiency to utilize assets for operational activities and provide information on company profitability measures. If ROI increases, the profitability of Islamic Bank increases so that the profit-sharing of mudharabah deposits will also increase.

Based on Islam (2018), Nofianti et al. (2015), NPF does not affect the profit-sharing of mudharabah deposits, but Huruniang (2015) concluded that there is an influence between NPF and the profit-sharing rate of mudharabah savings. This finding is likely Islami (2018) and Nofianti et al. (2015), that NPF insignificantly influenced to mudharabah deposits sharing the profit. This finding also supports another research from Choirudin and Praptoyo (2017), stated that amongst Deposits of Mudharabah (DM), Capital Adequacy Ratio (CAR), Non-Perfoming Financing (NPF), Financing to Deposit Ratio (FDR), and Operating Expenses to Operating Income (BOPO) to Mudharabah Financing, the variables that have an impact are Deposits of Mudharabah (DM), Capital Adequacy Ratio (CAR), and Financing to Deposit Ratio (FDR).

Meanwhile, the others harm mudharabah financing. The resultant research is in line with Winarsih (2019) research, which shows NPF negatively affects the financing of revenue share. It is because firstly, there is a backup plan that Islamic banks have done before. They keep maintaining their capital adequacy ratio in order to reserve a high level in NPF. These circumstances will lead to responsibility and trust between Islamic banks and their customers, hence the NPF level lower than in conventional banks. Secondly, Islamic Bank is cautious in selecting prospective borrowers, so there is a rigorous selection of prospective borrowers. It causes the moral hazard committed by the borrower to be minimal. This situation leads to the small NPF value that is in the bank. This policy is very different from conventional banking, which provides many loan funds to lower control over borrowers.

\section{Conclusion}

Using two variables, such as Return on Investment (ROI) and Non-Performing Funding (NPF), to assessing sharing profit in mudharabah deposits gives findings that the only ROI has a significant and positive impact mudharabah deposit sharing profit. In contrast with ROI, NPF has no impact on mudharabah deposit sharing profits. ROI is a measure of Islamic bank financial performance's success that significantly affects the profit-sharing rate of mudharabah deposits, even though fluctuations in exchange rates are very influential on the return on investment received. If ROI increases, the profit-sharing received by the customer will increase. Therefore, it is expected that all Islamic Sharia Banks in Indonesia can continue to improve their financial performance and maintain selected investments so that the level of profit-sharing from mudharabah deposits given to customers becomes sumptuous. Thus, depositors will continue to deposit their funds in Islamic banks that have enormous returns and are free from usury (interest).

\section{References}

Agustianto. (2005). “Penentuan Bagi Hasil Deposit Mudharabah di Bank Syariah”. Accesed at www.iaei-pusat.net.

Antonio, Syafiei. (2012). "Bank Syariah dari Teori ke Praktik. Jakarta: Gema Insani”.

Ascarya. (2011). “Akad dan Produk Bank Syariah”, Cetakan keempat. Jakarta: PT. Raja Grafindo Persada. 
Volume 3 Issue 6 (March 2021) PP. 37-50

DOI 10.35631/AIJBAF.36004

Choirudin, Ahmad dan Sugeng Praptoyo. (2017). “Analisis Faktor Yang Mempengaruhi Pembiayaan Bagi Hasil Mudharabah Pada Bank Umum Syariah." Accessed on 21 November 2019 at https://www.semanticscholar.org/.

Fahmi, Irham (2012). Analisis Laporan Keuangan. Cetakan Kedua. Bandung: Alfabeta

Farianto, Agus. (2014), “Analisis Pengaruh Return On Asset (ROA), BOPO dan BI Rate

Terhadap Tingkat Bagi Hasil Deposit Mudharabah Pada Bank Umum Syariah Di

Indonesia Tahun 2012-2013", Volume 2, No.1.

Faza, Zulfikar dan Ummiy Fauziyah Laily. (2018). "PENGARUH RETURN ON ASSET, RETURN ON EQUITY, DAN FINANCING TO DEPOSIT RATIO TERHADAP TINGKAT BAGI HASIL DEPOSIT MUDHARABAH (pada Bank Umum Syariah Periode 2012-2017”). El-Qist Vol. 08, No. 01, April 2018 ISSN 2252-7907

Fatwa DSN-MUI Nomor 3 Tahun 2000

Fatwa DSN No. 03/DSN-MUI/IV/2000

Husnelly. (2003). "Analisis Faktor-Faktor Yang Mempengaruhi Investasi Dana Masyarakat Pada Bank Syariah (Studi Kasus Pada BSM)”. Tesis. Jakarta: PSKTTI UI.

Ismail (2011). "Perbankan Syariah". Edisi I. Jakarta: Kencana.

Islami, Khansa Fairuz. 2018. "Analisis Pengaruh NPF (Non Performing Financing), FDR (Financing to Deposit Ratio), ROA (Return On Asset), dan BI Rate Terhadap Tingkat Bagi Hasil Deposit Mudharabah Bank Umum Syariah di Indonesia Tahun 2011-2015”. Universitas Islam Indonesia.

Jumingan. (2006). “Analisis Laporan Keuangan”, Cetakan Pertama. Jakarta: Bumi Aksara. Kasmir. (2011). “Analisis Laporan Keuangan”. Jakarta: PT. Raja Grafindo Persada.

Karim, Adiwarman A. (2007). "Bank Islam Analisis Fiqh dan Keuangan”, Jakarta: PT. Raja Grafindo Persada.

Mangkuto, Imbang Jayadi. (2004). "Pengaruh Tingkat Suku Bunga Deposit Bank Konvensional dan Tingkat Pendapatan Deposit Mudharabah Terhadap Pertumbuhan Deposit di Bank Muamalat". Tesis. Yogyakarta: PSKTTI UI

Muntoha Ihsan. (2011). "Pengaruh Gross Domestic Product, inflasi, dan Kebijakan Jenis Pembiayaan Terhadap Rasio Non Performing Financing Bank Umum Syariah di Indonesia Periode 2005 sampai 2010”. Skripsi. Semarang: Ekonomi Universitas Diponegoro.

Munawir, S. (2007). “Analisa Laporan Keuangan”. Yogyakarta: Liberty.

Nofianti, Nana, dkk (2015), “Analisis Pengaruh Return On Asset (ROA), Biaya Operasional Terhadap Pendapatan Operasional (BOPO), Suku Bunga, Financing To Deposit Ratio (FDR) dan Non Performing Financing (NPF) Terhadap Tingkat Bagi Hasil Deposit Mudharabah (Studi Empiris pada Bank Umum Syariah di Indonesia Tahun 20112013)", Jurnal Bisnis dan Manajemen, Volume 5, No.1.

Otoritas Jasa Keuangan. (2018). "Statistik Perbankan Syariah" diakses pada http://www.ojk.go.id

Peraturan Bank Indonesia Nomor 8/21/PBI/2006 tanggal 5 Oktober 2006 tentang Penilaian Kualitas Bank Umum

Peraturan Bank Indonesia No. 9/1/PBI/2007

Rizal, Ahmad. (2009). "pengaruh profitabilitas dan investmen opportunity set terhadap kebijakan deviden tunai". ISSN : 1979 - 5408 Vol. 2 No.2

Sudarsono, Heri (2007). "Bank dan Lembaga Keuangan Syariah”. Yogyakarta: Ekonisia

Sucipto. (2003). "Penilaian Kinerja Keuangan.” Jurnal Akuntansi. Universitas Sumatra Utara. Medan. 
Volume 3 Issue 6 (March 2021) PP. 37-50 DOI 10.35631/AIJBAF.36004

Tim Pengembangan Perbankan Syariah Institut Bankir Indonesia. (2001). "Konsep Produk dan Implementasi Operasional Bank Syariah”. Jakarta : Djambatan.

Undang-Undang No. 10 Tahun 1998 pasal 1 ayat 7

Undang-Undang No. 21 Tahun 2008 pasal 1 tentang Perbankan Syariah

Umiyati dan Shella Muthya Syarif. (2016). "Kinerja Keuangan dan Tingkat Bagi Hasil Deposit Mudharabah Pada Bank Umum Syariah Di Indonesia”. Jurnal Akuntansi dan Keuangan Islam Vol. 4, No. 1

Winarsih, Winarsih and Wanda Asokawati. (2019). "Determinant Of Implementation Profit Sharing Financing In Islamic Banking. IJIBE (International Journal of Islamic Business Ethics) Vol. 4 No. 1 March 2019.

Wiroso. (2005). "Penghimpunan Dana dan Distribusi Hasil Usaha Bank Syariah". Jakarta: Grasindo

Wiyono, Slamet (2005). “Cara Mudah Memahami Akuntansi Perbankan Syariah: Berdasarkan PASK dan PAPSI”. Jakarta: Grasindo 